\title{
, \\ SunSTONE LABRADORITE FROM THE Ponderosa Mine, Oregon
}

By Christopher L. Johnston, Mickey E. Gunter; and Charles R. Knowles

The Ponderosa mine is now producing commercial quantities of the gem-quality labradorite feldspar known as sunstone. This gem material exhibits unique optical and physical properties that include a wide range of saturated body colors, aventurescence, and strong pleochroism. The feldspar is $A n_{70}$ labradorite, a high calcic plagioclase; the aventurescence-causing inclusions have been identified as pure native copper. Microprobe analyses conducted on colorless, red, and green samples did not reveal any obvious causative mechanism for the exhibited colors, although ongoing research is investigating intervalence charge transfer, possibly involving colloidal copper. Gemological identification involves the use of R.I., S. G., and microscopy. Locality determination (Oregon) is based on the copper inclusions and a distinct pleochroism.

\footnotetext{
ABOUT THE AUTHORS

Mr. Johnston is a graduate student at the University of ldaho, Moscow, Idaho, as well as general partner and mine geologist at the Ponderosa mine. Dr. Gunter is assistant professor of mineralogy at the University of Idaho, and Mr. Knowles is a supervisory geologist and a senior researcher for the ldaho Geologic Sunvey, Moscow, Idaho.

Acknowledgments: C. Johnston would like to thank Larny Gray, Dr. G. A. Fossman, Dr. D. Peacor, and Charles and Virginia Weightman for their ongoing support.

Gems \& Gemology, Vol. 27, No. 4, pp. 220-233

(c) 1992 Gemological Institute of America
}

$\prod_{\mathrm{n}}$

n 1985, the Oregon legislature named the gem variety of labradorite called sunstone as the state gem. Currently, there are two known (and one reported) deposits of this gem mineral in Oregon: the initial discovery $33 \mathrm{~km}$ north of Plush in Lake County, south-central Oregon, which has been alternately referred to as the Plush, Lakeview, Rabbit Hills, or Rabbit Basin location; a small deposit reported near the White Horse Ranch in southeastern Harney County, in south-central Oregon; and the Ponderosa mine, in northwestern Harney County. The geology and mineralogy of the Plush deposit have been reported in varying detail by a number of researchers (Powers, 1932; Stewart et al., 1966; Peterson, 1972; Pough, 1983; and Hofmeister and Rossman, 1985).

The Ponderosa deposit was discovered in the summer of 1980, when a logging operation cut roads through the area. Lode claims were staked and pick-and-shovel mining activities began that summer. Mining activity has accelerated since then, and heavy equipment has been added to refine the extraction process. To date, $400 \mathrm{~kg}$ of gem-quality rough sunstone have been removed from the Ponderosa mine, $140 \mathrm{~kg}$ in 1991 alone. As a result, Ponderosa mine sunstone-in a variety of colors-has begun to find its way into the general gem and jewelry market (figures 1 and 2).

Extensive study of the Ponderosa mine sunstone labradorite has revealed a number of distinctive characteristics, including aventurescence and pleochroism, as well as provided information to help determine the cause of the different colors. This sunstone can be readily identified on the basis of its gemological properties.

\section{LOCATION AND ACCESS}

The Ponderosa mine is located in northwestern Harney County, approximately $330 \mathrm{~km}$ (220 mi.) west of Boise, 


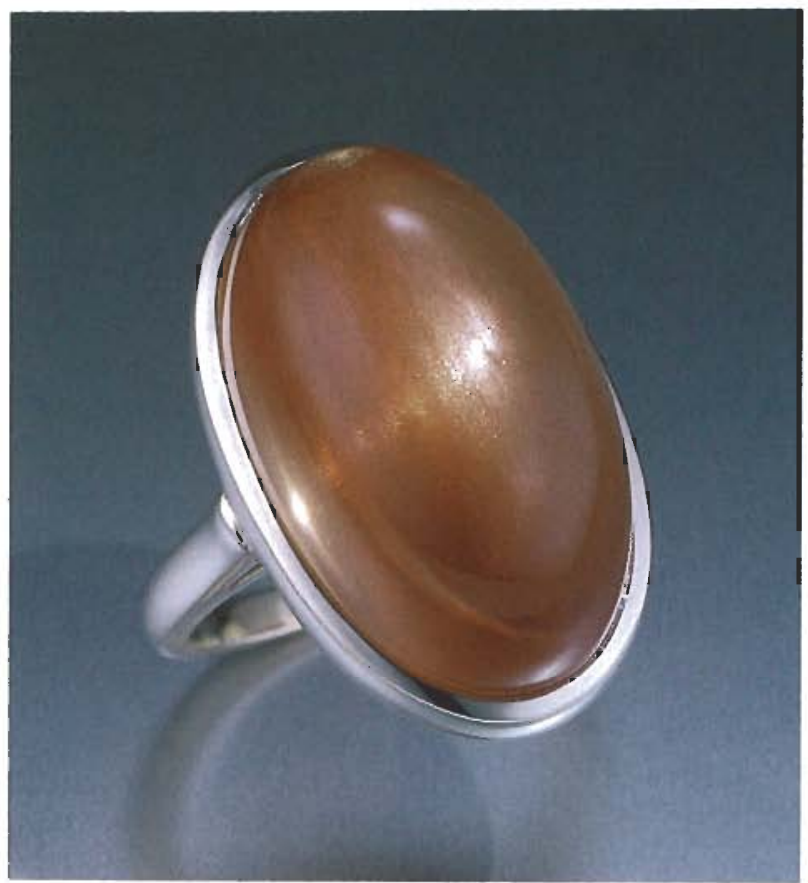

Figure 2. Ponderosa mine sunstone is now appearing in the international jewelry market. Tiffany produced this 29.78-ct cabochon ring set in silver as part of a line of sunstone jewelry the firm will be promoting. Photo (C) Tino Hammid. and summit of the butte. The contacts between the four flows are characterized by the scoria on top of each flow and by intraflow lithology. (Scoria is a volcanic slag or pyroclastic ejecta, partly crystalline and partly glassy, that forms as the molten rock degases and creates a froth.) Basalt b (figure 4) is so far the only flow at the Ponderosa mine that contains large gem labradorite phenocrysts.

There are only minor physical and chemical differences between basalts $a, b, c$, and d, other than alteration and weathering effects. Flow $\mathrm{b}$ is thicker $(25-30 \mathrm{~m})$ than the other three flows (15-20 m each) and has a more scoriaceous and porphyritic character. Field studies indicate that portions of flow $b$ have undergone extensive weathering or alteration. It is not known whether this alteration is the result of true secondary hydrothermal alteration; of molten rock interaction with groundwater or standing surface water at the time of extrusion; or of flow b being a water-affected-basalt (Jenks and Bonnichsen, 1989). Flows a, c, and d and the non-gem-bearing, nonweathered portion of flow $b$, on the other hand, exhibit limited or minor weathering. When rock is exposed to hydrothermal fluids, a suite of secondary minerals is normally associated with the interaction of the hot fluids and the host rock. However,

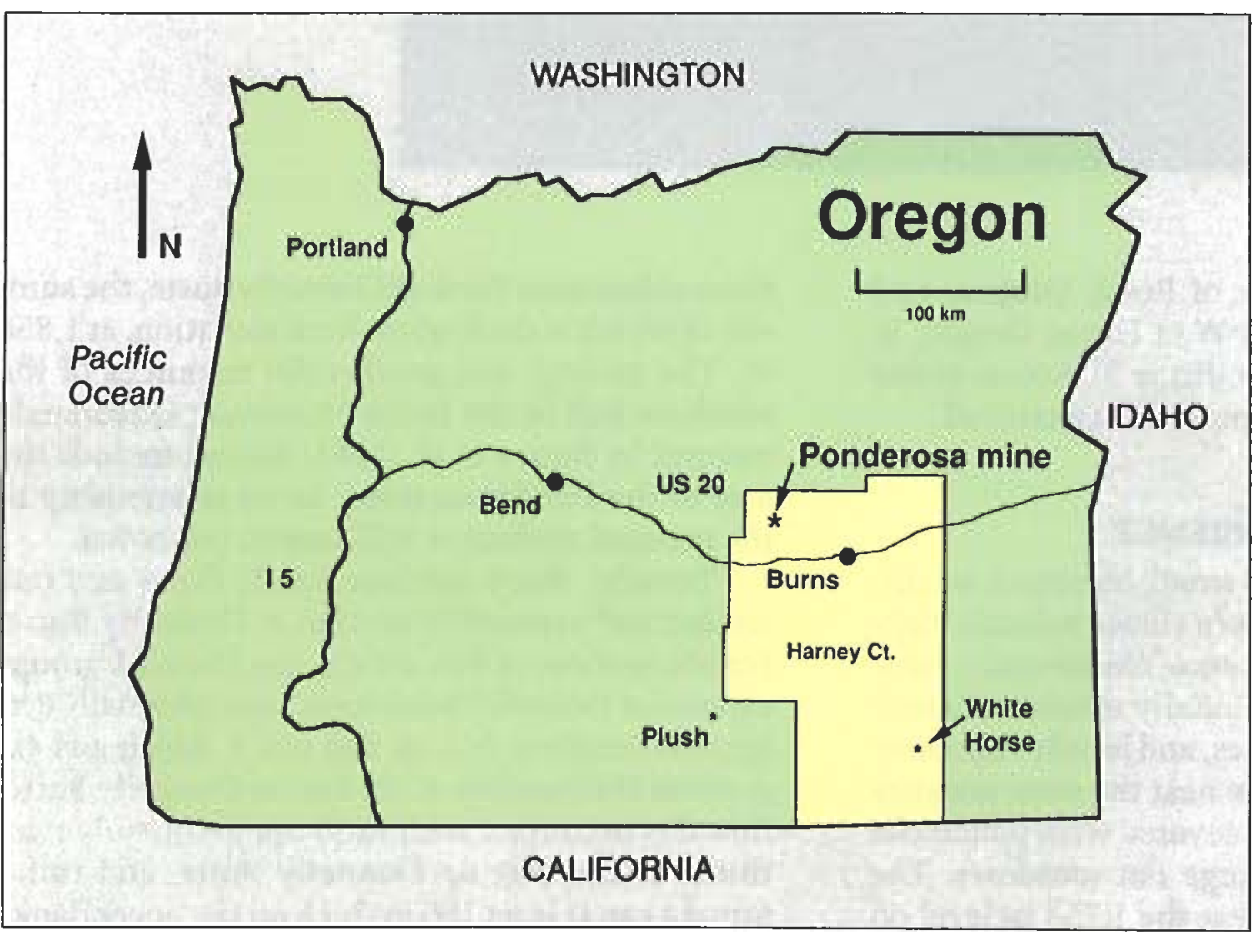

Figure 3. This map shows the location of the Ponderosa mine in northwestern Harney County, south-central Oregon. Also noted are the Plush and White Horse mines. Map by C. Johnston and $M$. Gunter. 
with the exception of one hand-size specimen that shows an encrustation of botryoidal chalcedony, there is no evidence of hydrothermal alteration. The physical evidence that flow $b$ is a water-affected basalt is a little stronger, given the weathering character and amounts of clays present as feldspar alteration (Jenks and Bonnichsen, 1989).

The age of the Ponderosa mine rock section has not yet been determined, but the Lakeview occurrence has been proposed as Steens Mountain equivalent, which is mid-Miocene-approximately 12 million years old (Stewart et al., 1966; Hofmeister and Rossman, 1985). Strike and dip data from flows $b$ and $c$ suggest little or no tectonic displacement.

Flow $b$ is characterized as a moderately to heav. ily weathered scoriaceous porphyritic basalt, identified as calc-alkaline by whole-rock chemical and electron microprobe analyses. It is composed of labradorite feldspar and basaltic glass, with minor olivine and magnetite/ilmenite present as accessory phases. The vesicles are filled to varying amounts with nonspecific clay and feldspar alteration products. Analysis has shown two distinct size groups of labradorite phenocrysts in flow b: Type L phenocrysts range from $1 \mathrm{~cm}$ to $10 \mathrm{~cm}$ in length and weigh up to 500 grams; type $S$ are an order of magnitude smaller and dominate the groundmass. Only the type $\mathrm{L}$ material has gem potential. To date, mining has shown the gem-quality crystals to be randomly distributed throughout the weathered portion of flow b. Although there appear to be certain trends within the pit where specific grades of gem crystals will occur, no clear model for prediction has been formulated.

The gem-bearing zone in flow b strikes $\mathrm{N} 10^{\circ} \mathrm{W}$, with exposures of gem crystals for approximately $700 \mathrm{~m}$ along the $\mathrm{N} 10^{\circ} \mathrm{W}$ trend. The main mine pit is located in the approximate center of this $700-\mathrm{m}$ strike length (figure 5). The gem-bearing horizon exposed in the main pit and downslope to the west is approximately $130 \mathrm{~m}$ wide. The eastern extent of the gem-bearing portion of flow $\mathrm{b}$ is unknown, as it is covered by the base of flow $\mathrm{c}$. Excavation in the 1991 mining season showed the gem-bearing horizon to be at least $7 \mathrm{~m}$ thick in the main pit, with no indications that the bottom of this gem-bearing horizon has been reached. Conservative projections suggest a total reserve of 500,000 metric tons of ore that contain an estimated 200 metric tons of gem material.

At the northern end of the main pit are extremely weathered, strongly altered, gem-bearing

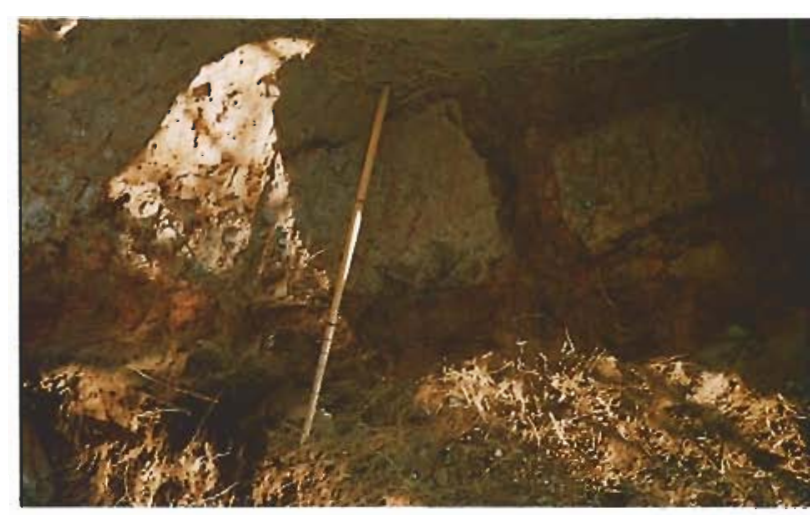

Figure 4. Sunstone is found only in the heavily weathered basalt flow $b$. The Jacobs staff is 1.3 m for scale. Photo by C. Johnston

zones that are essentially unconsolidated earth (again, see figure 5) with a non-gem-bearing overburden of biota-rich chocolate brown. The groundmass of these in-situ deposits, the depth of which has yet to be determined, is differentiated by its bright reddish brown color and slightly granular texture. Although these zones have produced small quantities of gem material relative to the total overall feldspar phenocryst content/roughly $1 \mathrm{~kg}$ of mixed gem-grade materials for every $10 \mathrm{~kg}$ of material mined), they are the source of the largest, finest facetgrade gems found thus far, including the 10.79-ct Ponderosa Queen (figure 6). Moreover, to date all of the red-and-green pleochroic material (discussed below) has come from this area.

The central area of the main pit contains rock that is less weathered but still strongly altered. This area has consistently produced the finest cabochongrade gems with deep red body color, as well as most of the smaller (5 ct and under) red facet-grade gems (figure 7).

The southem end of the main pit has produced the highest ratio of gem material to total feldspar mined-8 kg: $10 \mathrm{~kg}$. However, approximately $85 \%$ of the gem crystals have little or no body color. The remaining $15 \%$ are small (less than $2.5 \mathrm{ct}$ ) red facetand cabochon-grade stones.

\section{MINING AND PROCESSING}

Frorn 1980 through 1988, mining activities at the Ponderosa mine were limited to a series of approximately 12 small hand-excavated prospect 


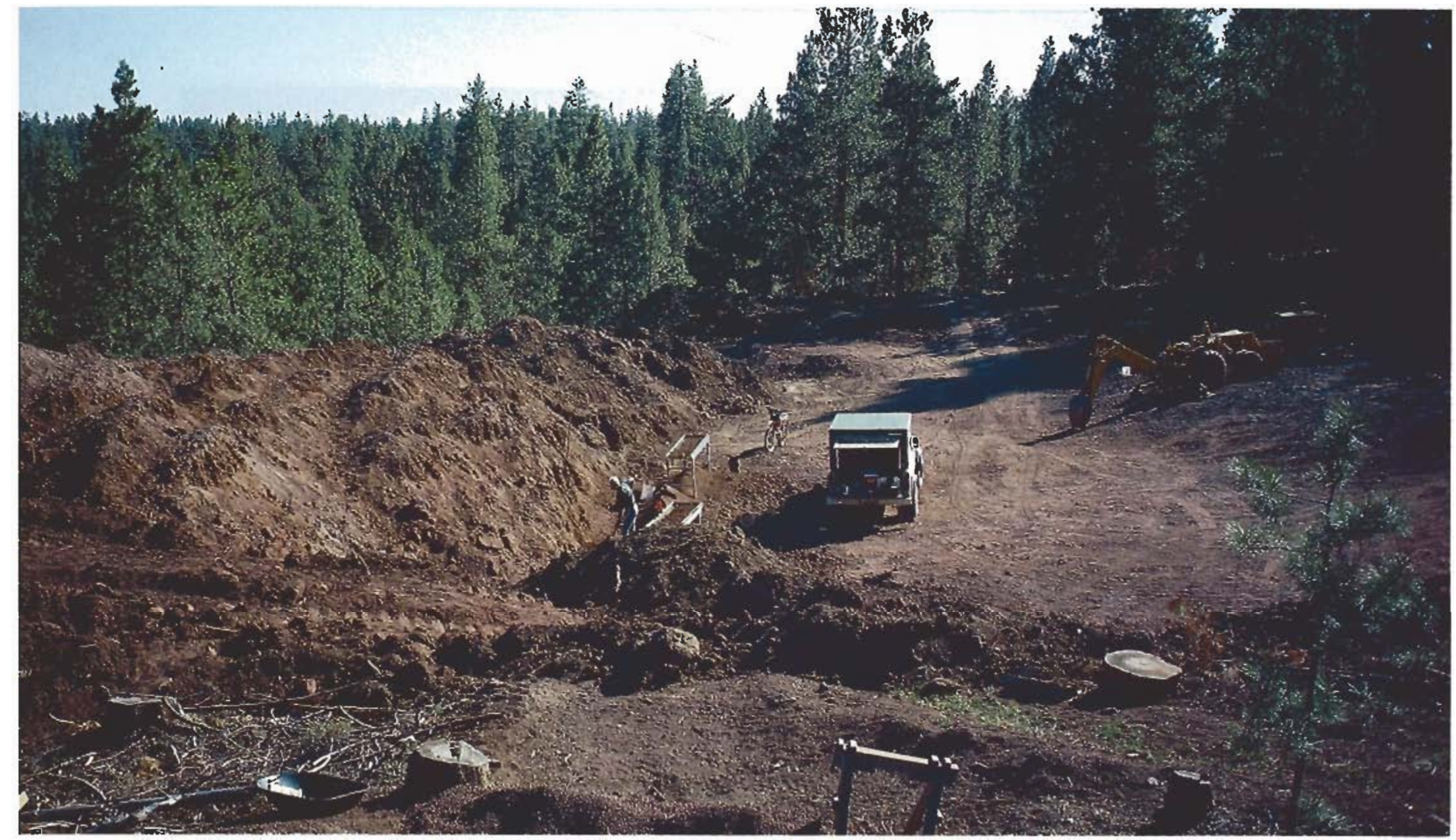

Figure 5. This view of the main pit of the Ponderosa mine is taken from the north looking south. Photo by C. Johnston.

Figure 6. The 10.79-ct "Ponderosa Queen," the largest deep red faceted sunstone in the world, was mined at the northern end of the main Ponderosa pit. Note also that the copper inclusions that cause the characteristic aventurescence of Ponderosa mine sunstone are clearly visible. Photo by Robert Weldon.

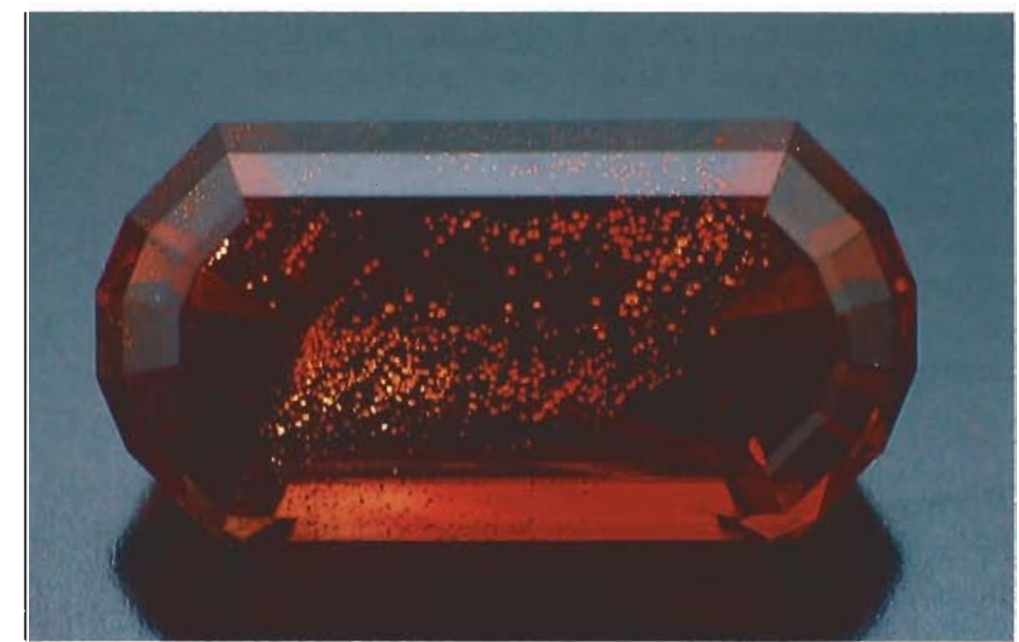

pits, most of which never exceeded $5 \mathrm{~m}^{2}$ and $3 \mathrm{~m}$ in depth. In 1989, the transition was made from a manual, pick-and-shovel operation to mechanized mining with a backhoe. By the end of the 1990 season, the pit begun in 1989 was enlarged to approximately $20 \mathrm{~m}^{2}$ and $5 \mathrm{~m}$ deep. In 1991, a bulldozer was used to excavate what is now the main pit, approximately $100 \mathrm{~m}^{2}$ and $5 \mathrm{~m}$ in depth, for which the main ore pile is about $1500 \mathrm{~m}^{3}$ (again, see figure 5). The estimated gem reserves in all currently stockpiled ore are 1.5 metric tons, or $15,000,000$ carats of all grades.

The average mining season is a little more than six months. The 1990 season ran from April 1st through December 15th, limited primarily by daylight and temperature, while the 1991 mining season ran from June 10th until October 15th, owing to snowstorms in June and October. The mine is typically worked by three full-time and two part-time miners.

Gem-bearing material is removed from most areas of the mine with a backhoe in conjunction with a bulldozer, jackhammers, explosives, and hand tools. However, at the northern end of the main pit, where 
the largest and finest material is usually found, only the backhoe and hand tools are used. As the hardness of the rock increases with depth in the central area of the main pit, jackhammers and explosives are required to loosen the ore.

Once the host basalt has been loosened and the backhoe has loaded its front bucket, it moves to the screening area on the mine dump (figure 8). At this point, the material is slowly loaded onto a oneinch-mesh frame-mounted grizzly for sorting. After inspection, material greater than one inch in diameter is broken down with 5-1b. hammers, since crystals larger than one inch are common. Barren material is dropped off the rear end of the screen complex. The material that passes through the grizzly is conveyed to a 25 - $\mathrm{ft}$.-long (about $8 \mathrm{~m}$ ), inclined, quarter-inch-mesh shaker screen, where the smallest pieces are removed for sorting. Screen fractions greater than a quarter inch and less than one inch are stored at the bottom of the shaker screen and later examined for feldspar crystals. Final screening is done on horizontal, roller-mounted, quarter-inch

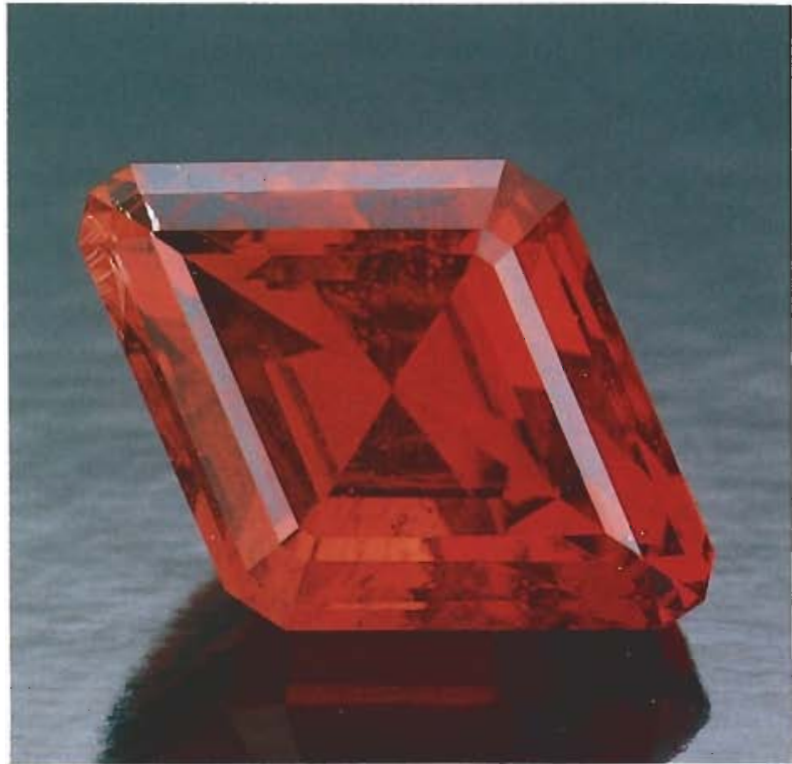

Figure 7. This fine 5.04-ct sunstone was found in the central area of the main pit. Photo $\mathbb{C}$ Tino Hammid.

Figure 8. For recovery of the gem labradorite, the backhoe moves the loose basalt to the main screening site, where it is transferred to the screen complex (middle background) for initial sorting and then to the inclined shaker screen (right background) for removal of the smallest pieces. Photo by C. Johnston.

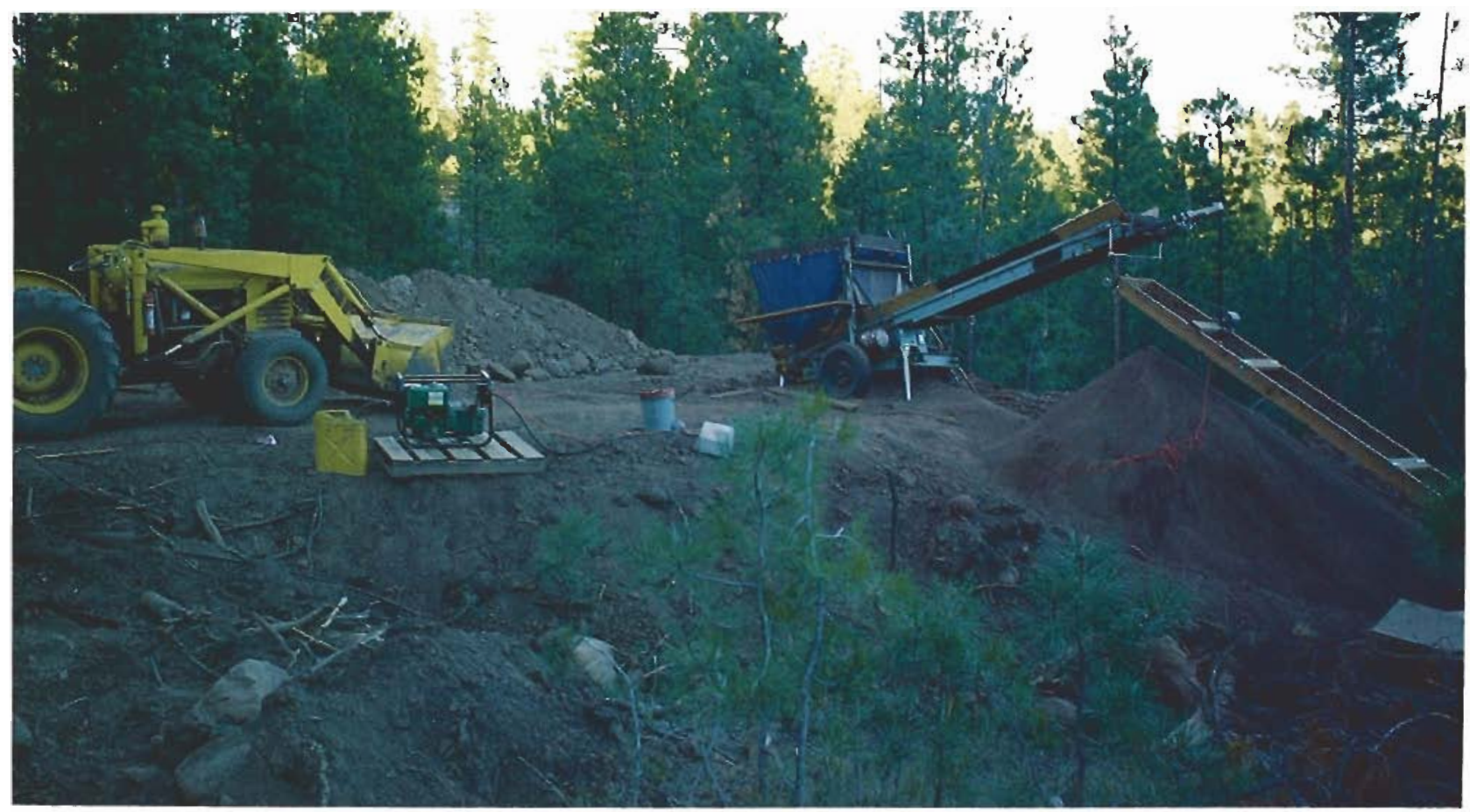


screens (figure 9). This final inspection process requires great care, as the feldspar crystals are often difficult to see. Gravity concentration cannot be used, because there is little difference in specific gravity between the waste basalt rock and the gem feldspar.

After the gem material is removed from the horizontal sorting screens, the day's production is tumbled and cleaned. The sunstone is then clipped, using carbide-tipped tile nippers, to remove visible flaws and produce the cleanest possible rough material for cutting. To maximize production, little effort is made to pre-sort the labradorite phenocrysts in the mine pit. After cleaning and tumbling, nongem materials are discarded. The remaining gem material is sorted for facet grade and the finest cabochon grades, as well as according to where it will be cut. Currently, the finest facet-grade rough that will produce finished gems larger then one carat is cut in the United States, as are the finest large cabochongrade pieces. Commercial sizes and grades of facet and cabochon materials are cut in Asia. All overseas cutting is now calibrated in whole sizes to satisfy manufacturers' specifications.

During the 1991 mining season, daily production averaged approximately $2 \mathrm{~kg}$ of all grades. Highgrade materials, including top facet and cabochon

Figure 9. Mine owner Larry Gray works the quarter-inch roller-mounted final soring screens at the Ponderosa mine. Photo by C. Johnston.

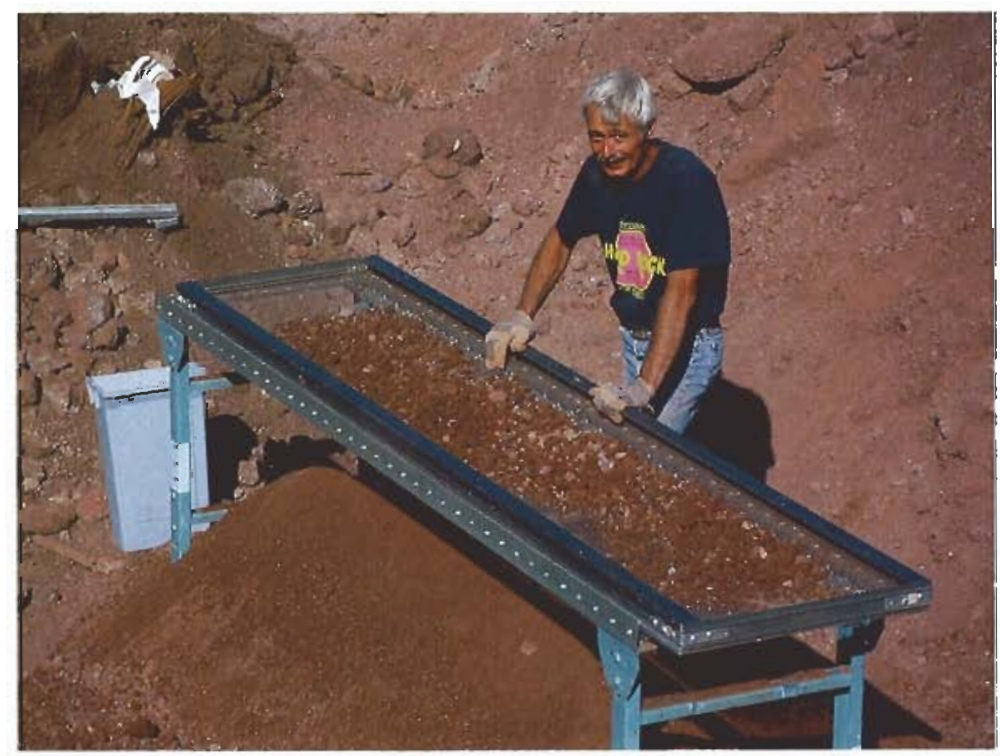

materials, account for approximately $25 \%$, or 500 grams per day. The remaining $1.5 \mathrm{~kg}$ consist of lower grades and smaller sizes of cabochon materials. The average weight of facet-grade rough is 0.5 to 3 grams. The average weight of cabochon materials is slightly larger, at 3 to 5 grams. The largest top red facet-grade rough found to date weighed 15.3 grams and produced a 10.22-ct carving (figure 10) and two smaller stones ( 2.49 and $3.58 \mathrm{ct}$ ). The largest fine cabochon rough produced to date weighed 36.5 grams. Distribution of Oregon sunstone, with the exception of two minor claim holders at Plush, is handled exclusively by the Ponderosa Mine Inc., Boise, Idaho.

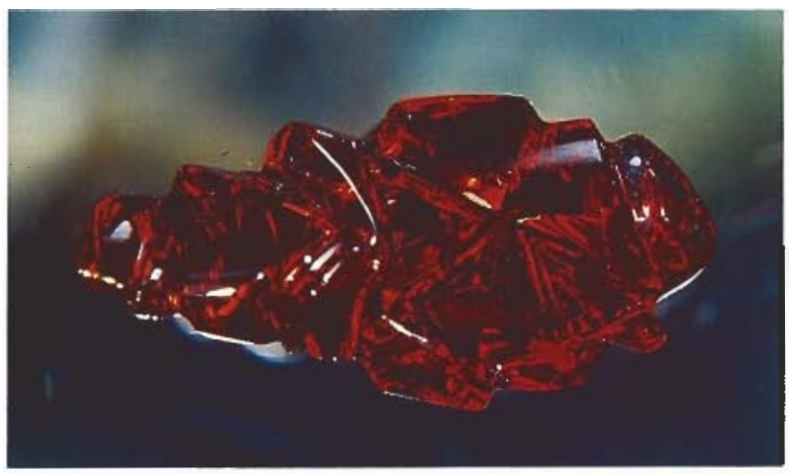

Figure 10. This 10.22-ct carving-the third largest known fashioned red sunstone-is one of three stones produced from the largest piece of facet-grade rough yet recovered from the Ponderosa mine. The rough weighed 15.3 grams. Carving by L. Gray; photo by C. Johnston.

\section{DESCRIPTION OF THE GEM MATERIAL}

Chemical (electron microprobe; table 1) and optical (Michel Lévy and spindle stage) analyses have shown that the Ponderosa mine phenocrysts have an albite/anorthite ratio of $\mathrm{Ab}_{30} / \mathrm{An}_{70}$, which places the feldspar at the labradorite/bytownite boundary. On the basis of extinction angles and refractive indices (see below), as well as host-rock lithology, the gem phenocrysts from the Ponderosa mine were identified as labradorite.

Crystal Habit. Labradorite is triclinic, for which the only possible crystal forms are pinacoids (forms 


\begin{tabular}{|c|c|c|c|c|}
\hline \multirow[b]{2}{*}{ Element } & \multicolumn{3}{|c|}{ Sample } & \multirow{2}{*}{$\begin{array}{l}\text { Detection } \\
\text { limit }\end{array}$} \\
\hline & 1 & 2 & 3 & \\
\hline \multicolumn{5}{|c|}{$\begin{array}{l}\text { Normalized } \\
\text { results (wt. \%) }\end{array}$} \\
\hline $\mathrm{SiO}_{2}$ & 51.76 & 52.05 & 51.52 & 0.028 \\
\hline $\mathrm{Al}_{2} \mathrm{O}_{3}$ & 30.43 & 29.98 & 30.61 & 0.019 \\
\hline $\mathrm{FeO}^{\circ}$ & 0.38 & 0.43 & 0.39 & 0.061 \\
\hline $\mathrm{CaO}$ & 14.16 & 14.23 & 14.34 & 0.021 \\
\hline $\mathrm{Na}_{2} \mathrm{O}$ & 3.18 & 3.24 & 3.10 & 0.022 \\
\hline $\mathrm{K}_{2} \mathrm{O}$ & 0.04 & 0.05 & 0.04 & 0.021 \\
\hline CuO & bdll & bdl & bdl & $0.080-0.092$ \\
\hline \multicolumn{5}{|c|}{$\begin{array}{l}\text { "Analyses were performed on a JEOL } 8600 \text { electron microprobe operating at } 15 \mathrm{keV} \text { with a beam diameter of } 0.5 \mathrm{~mm} \text {; } \\
\text { standard ZAF corrections were made; bdl = below detection limits. Ni, } \mathrm{V} \text {, and } \mathrm{Cr} \text { were also tested for but not detected } \\
\text { above the limits of instrumentation and operating conditions. } \\
{ }^{\circ} \text { Sample } 1 \text { was transparent and colorless; sample } 2 \text { was red; sample 3, green. } \\
\text { "All iron reported as FeO. }\end{array}$} \\
\hline
\end{tabular}

composed of two parallel faces|. Common forms encountered include basal pinacoids $\{001\}$, side pinacoids $\{010\}$, and front pinacoids $\{100\}$. The large type $\mathrm{L}$ phenocrysts from flow $b$ at the Ponderosa mine typically" exhibit excellent crystal form (figure 11). When phenocrysts are encountered in place in the flow, they exhibit good crystal form. Because of the differential cooling rates between the phenocrysts and the enclosing basalt, however, the crystals are usually fractured; when they are separated from the matrix, they typically come out in fragments.

The labradorite crystals from the Ponderosa mine commonly exhibit albite, pericline, and Carlsbad twinning. Albite twin lamellae are often visible with the naked eye and range from $1 \mathrm{~mm}$ to $5 \mathrm{~mm}$ in thickness. Carlsbad and pericline twinning are less common and are visible only in thin section.

Aventurescence. All Ponderosa gem-quality labradorite crystals exhibit varying intensities of aventurescence (see figures 1, 2, 5, and 6), a light-reflectance phenomenon caused by the crystallographically planar arrangement of macroscopically visible inclusions (figure 12). Often the intensity of the aventurescence is a direct result of the metallic luster and size of the inclusions, as well as the sheer number present in a given crystal. When present in stones that lack distinct body color, the aventurescence can actually impart a pink or orangyyellow appearance to the stone. The inclusions in Ponderosa mine sunstone have a large surface area, up to $100 \mu \mathrm{m}$ in diameter. However, these lamellae have a cross-section of less than $500 \mathrm{~nm}$. Note that, although these inclusions are confined to discrete planes, they are randomly distributed within these planes.

Figure 11. Ponderosa-mine labradorite crystals typically exhibit excellent form. This line drawing shows crystallographic axes $(a, b, c)$ and optical directions $(X, Y, Z)$ of a labradorite crystal.

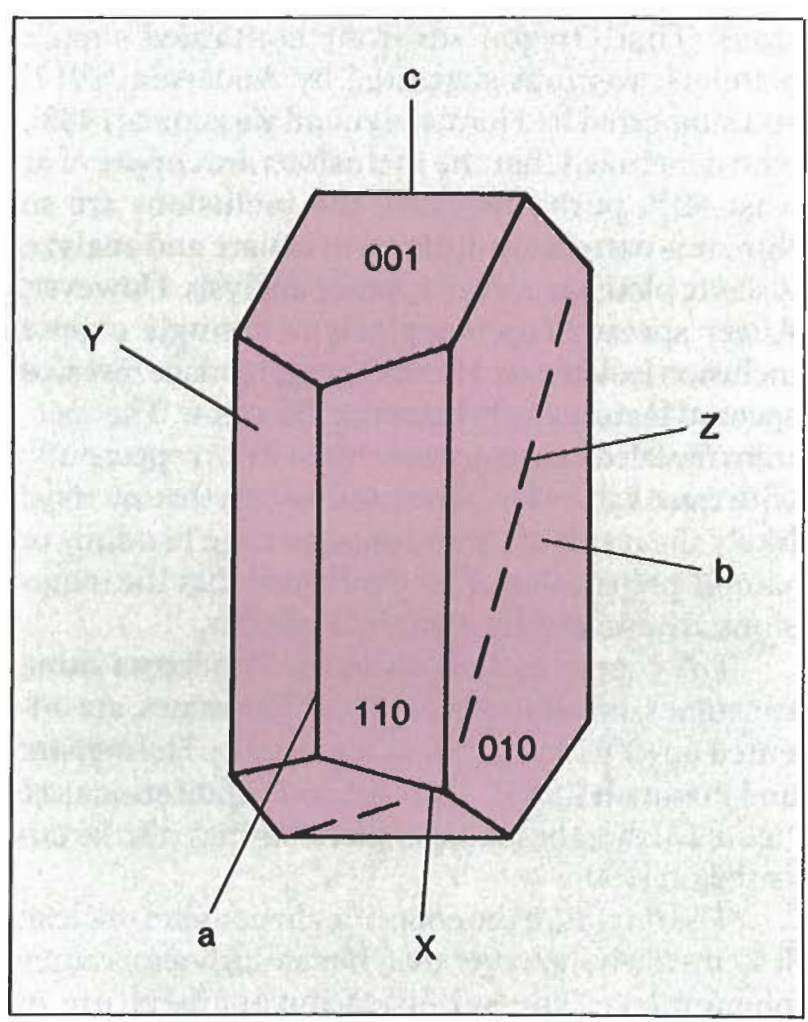


phase coming out of solution [not necessarily water] as the result of changing pressure and temperature; D. Peacor pers. comm., 1991). The specific thermodynamic mechanisms and the means of initial platelet nucleation are not known at this time. What is clear is that the physical location of the copper platelets within the phenocrysts was controlled crystallographically, as evidenced by their distinctly planar alignments parallel to crystallographic twin planes (figure 14).

In all cases, sunstones from the Ponderosa mine exhibit copper inclusions. Thus far, we have seen no pieces that appear flawless when examined with $10 \times$ magnification. Therefore, the presence of copper platelets can be viewed as a characteristic fingerprint of Oregon origin.

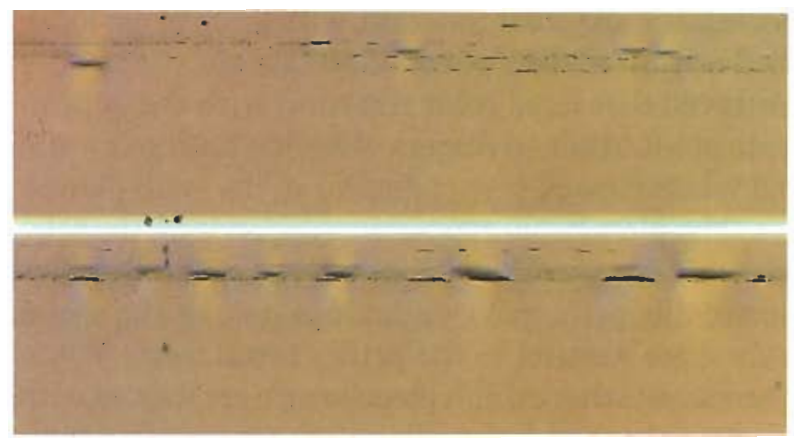

Figure 14. This photomicrograph of a labradorite phenocryst thin section shows the distinctly planar relationship between the copper platelets and the 1010$\}$ twin plane. Taken at $25 \times$ magnification on an Olympus polarizing light petrographic microscope; by C. Johnston.

Color. The Ponderosa mine labradorite crystals exhibit a dramatic range of body colors, including pale yellow, pale yellowish orange, pale pinkish orange, pink, red-orange, deep red, pale green, and blue-green, as well as colorless (again, see figure 1). This range and the generally high saturation of body color are unique to the Ponderosa deposit. Rarest are the bright saturated greens, of which fewer than 20 stones have been recovered each year. Fine saturated green stones rarely exceed one carat, and the largest recovered to date yielded a 1.78-ct round brilliant (figure 15). Only slightly more commonfewer than 30 stones per year-are the bright, sharply bi- and tri-colored stones (figure 16). Much more common are the various shades of red, of which those

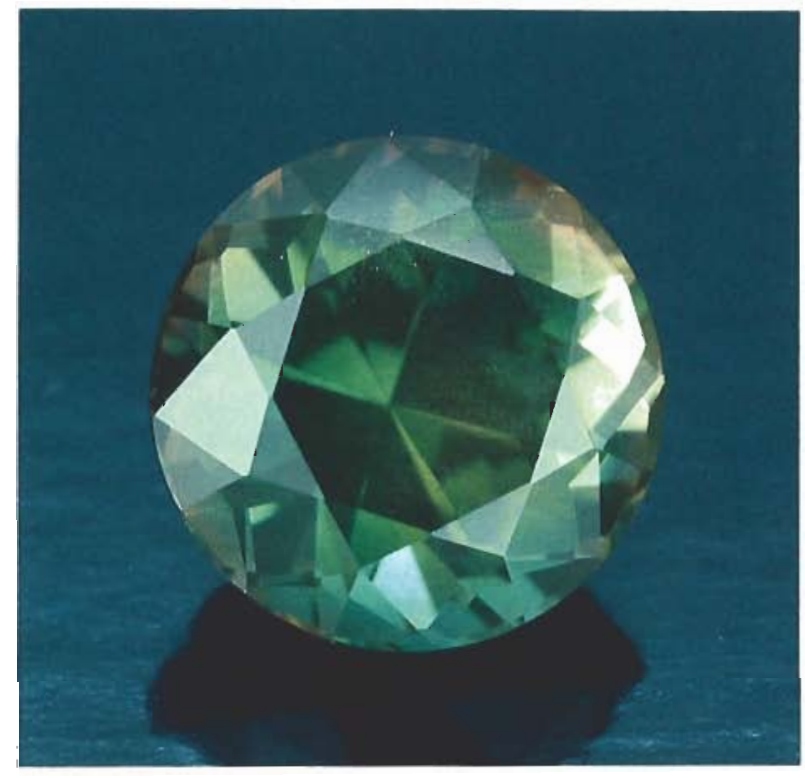

Figure 15. Green is the rarest color variety of Oregon sunstone. This 1.78-ct sunstone is from the Ponderosa mine. Photo (C) Tino Hammid.

with a deep uniform red are the most sought after (again, see figures 6 and 7).

Color in Oregon sunstone is little affected by change in light intensity; these sunstones charac-

Figure 16. The Ponderosa mine also produced this exceptional 1.84-ct bicolored sunstone. Photo (c) Tino Hammid.

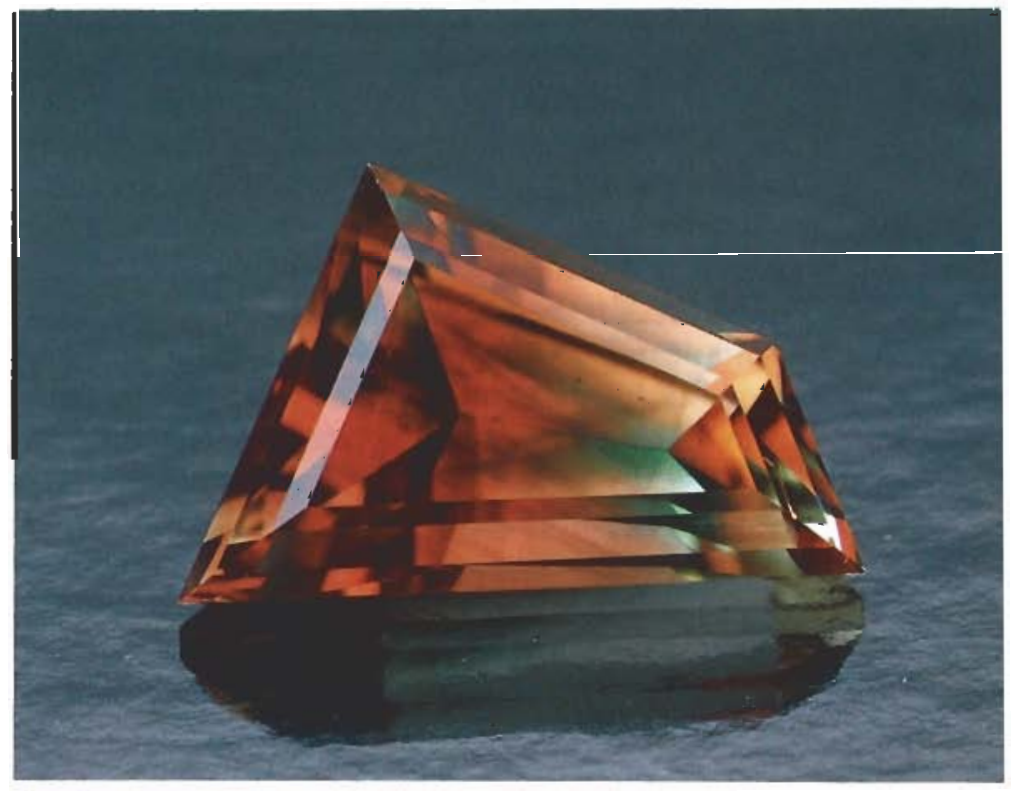


teristically stay "bright" in low or indirect light, whereas many colored gems "die" in low-light conditions. Those stones that have a very strong or saturated green direction (see "Pleochroism" below) are often too dark and, when faceted, become translucent to opaque. This is because higher concentrations of aventurescence-causing inclusions are commonly associated with these strongly pleochroic stones, which accounts for the rarity of fine, brilliant green sunstones. Conversely, saturated red stones seldom exhibit such density of copper inclusions.

Hofmeister and Rossman (1985) reported a specific sequence for color zonation in the Plush material in which green always encircles red and the color boundaries between red and green tend to be sharp. The Ponderosa crystals exhibit a less regular pattern of color sequence and zonation. The exception is that, whatever the color sequence, color zones are always bounded by transparent, colorless zones that extend to the crystal surface.

Although the physical evidence shows extreme variation in color, long-count microprobe study has shown little difference in bulk chemistry from one color variety to the next (table 1 ). X-ray fluorescence analysis did show significant differences in copper content among nonaventurescent colorless (9 ppm), deeply colored nonpleochroic red (114 ppm), and pleochroic green (84 ppm) crystals (table 2), but any conclusions as to the causes of color based on observed variations in chemistry from colorless through red and green are at this juncture speculative.

Hofmeister and Rossman (1985) suggested that the color in the Plush labradorite is a result of intervalence charge transfer (IVCT) involving copper; trace-element chemistry, as determined using X-ray fluorescence analysis, seems to support this theory. If color is the result of either intervalence charge transfer or the interference effects of intra-lattice colloidal copper, then it will be impossible to isolate a sample free of copper influence, as there would be a smooth linear trend of copper from atomic-level colloids through the megascopically visible platelets. As Nassau (1983) points out, however, ionic concentrations in the range of 0.01 to $0.09 \mathrm{wt} \%$ have been shown to cause intense color in minerals by IVCT. He also suggests that the lower concentration limits that will induce color are unknown. Additional support comes from papers on color in glass caused by colloidal metals (Hopkins and Brown, 1991; Stookey et al., 1978).
Pleochroism. Perhaps the single most striking feature of the Ponderosa sunstone is the strong pleochroism seen in some of the red and green material. Because labradorite belongs to the triclinic crystal system, it is biaxial and can show three directions of pleochroism. Yet labradorites, and feldspars in general, are not normally pleochroic.

Some uniformly red crystals do not show green in any orientation; however, all green crystals have at least one red direction. There are also occurrences of two red directions and a single green direction. Unlike other pleochroic biaxial minerals, whether the third direction is red or green it exhibits the same tone of color as the corresponding direction. Figure 17 shows a generalized relationship between crystal form and pleochroism.

The Ponderosa pleochroic material at times exhibits a strong correlation between twin-plane boundaries and color zonation, with green or red localized within a twin plane. Crystals are commonly observed that have color zonation with the appearance of intertwined fingers, showing both green and red when viewed perpendicular to the twin planes.

The pleochroic appearance depends on the relationship of exhibited color to twin planes. In labradorite, the principal twin planes (i.e., of the albite twins) are parallel to the $\{010\}$ crystal form. When phenocrysts that exhibit pleochroism are viewed with plane polarized light vibrating perpendicular to $\{010\}$, they exhibit a red body color. Conversely, when viewed with plane polarized light parallel to $\{010\}$, they exhibit a green body color. The exact relationship between color and crystallographic axis is the subject of ongoing research.

Refractive Indices and Birefringence. Using a Gem Duplex $\Pi$ refractometer and a sodium vapor $(589 \mathrm{~nm})$ light source, refractive indices were obtained for 20 typical, randomly oriented, twinned, faceted samples (see table 3). These refractive indices are close to those reported for labradorite in general $\{\alpha=1.560, \beta=1.564, \gamma=1.568)$ and correlate well with those of $\mathrm{An}_{70}$ specifically (i.e., around 1.569).

In addition, a detailed optical study was undertaken to determine the precise refractive indices and optical orientation of a clear, colorless Ponderosa mine labradorite crystal, using techniques described by Emmons (1928), Bloss (1981), and Gunter et al. (1989) that allow refractive indices to be calculated to approximately \pm 0.0002 . Calibrated liquids were used with a research-grade Leitz polarizing 
TABLE 2. Results of XRF chemical analyses ${ }^{\mathrm{a}}$ of four Ponderosa mine sunstone labradorites.

\begin{tabular}{|c|c|c|c|c|}
\hline \multirow[b]{2}{*}{ Element } & \multirow[b]{2}{*}{1} & \multicolumn{2}{|c|}{ Sample number ${ }^{b}$} & \multirow[b]{2}{*}{4} \\
\hline & & 2 & 3 & \\
\hline \multicolumn{5}{|c|}{$\begin{array}{l}\text { Normalized } \\
\text { results (wt.\%) }\end{array}$} \\
\hline $\mathrm{SiO}_{2}$ & 51.11 & 51.83 & 50.93 & 51.03 \\
\hline $\mathrm{Al}_{2} \mathrm{O}_{3}$ & 31.01 & 30.51 & 31.20 & 31.13 \\
\hline $\mathrm{FeO}$ & 0.31 & 0.32 & 0.29 & 0.29 \\
\hline $\mathrm{CaO}$ & 14.09 & 13.43 & 14.23 & 14.12 \\
\hline $\mathrm{Na}_{2} \mathrm{O}$ & 3.36 & 3.74 & 3.24 & 3.31 \\
\hline $\mathrm{K}_{2} \mathrm{O}$ & 0.05 & 0.11 & 0.05 & 0.05 \\
\hline $\mathrm{TiO}_{2}$ & 0.047 & 0.043 & 0.045 & 0.044 \\
\hline $\mathrm{P}_{2} \mathrm{O}_{5}$ & 0.007 & 0.009 & 0.008 & 0.008 \\
\hline $\mathrm{MnO}$ & 0.001 & 0.010 & 0.011 & 0.010 \\
\hline \multicolumn{5}{|c|}{$\begin{array}{l}\text { Trace elements } \\
\text { (ppm) }\end{array}$} \\
\hline $\mathrm{Ni}$ & 5 & 6 & 7 & 6 \\
\hline $\mathrm{Cr}$ & 1 & nd & nd & nd \\
\hline $\mathrm{Ba}$ & nd & 17 & nd & nd \\
\hline $\mathrm{Rb}$ & 2 & 3 & 2 & 3 \\
\hline $\mathrm{Sr}$ & 446 & 614 & 444 & 454 \\
\hline $\mathrm{Zr}$ & 26 & 32 & 27 & 26 \\
\hline $\mathrm{Nb}$ & 4.7 & 5.3 & 6.2 & 5.9 \\
\hline $\mathrm{Ga}$ & 11 & 13 & 10 & 12 \\
\hline $\mathrm{Cu}$ & 9 & 114 & 84 & 110 \\
\hline $\mathrm{Zn}$ & 3 & 4 & 4 & 1 \\
\hline $\mathrm{Pb}$ & 2 & 2 & 1 & 1 \\
\hline $\mathrm{Ce}$ & 1 & 10 & 7 & nd \\
\hline Th & nd & 2 & 2 & 1 \\
\hline \multicolumn{5}{|c|}{$\begin{array}{l}\text { analyses were performed on a Rigaku } 3370 \mathrm{XRF} \text { spectrometer using a fused sample-lithium tetraborate } \\
\left(\mathrm{Ci}_{2} \mathrm{~B}_{4} \mathrm{O}_{7}\right) \text { glass disc and Rhodium target at } 50 \mathrm{KV}, 50 \mathrm{ma} \text {, and full vacuum. Data were corrected for matrix } \\
\text { effects and line inferferences. nd =not detected. Mg, SC, V, Y, and La were also tested for but not detected } \\
\text { at the trace level in any of the samples. } \\
\text { bSample } 1 \text { was transparent and colorless; sample } 2 \text { was intense red along all three optical directions; sample } \\
3 \text { was pleochroic with green body color along one direction and red body color along two directions; sample } 4 \\
\text { was pleochroic with green body color along two directions and red body color along one direction. }\end{array}$} \\
\hline
\end{tabular}

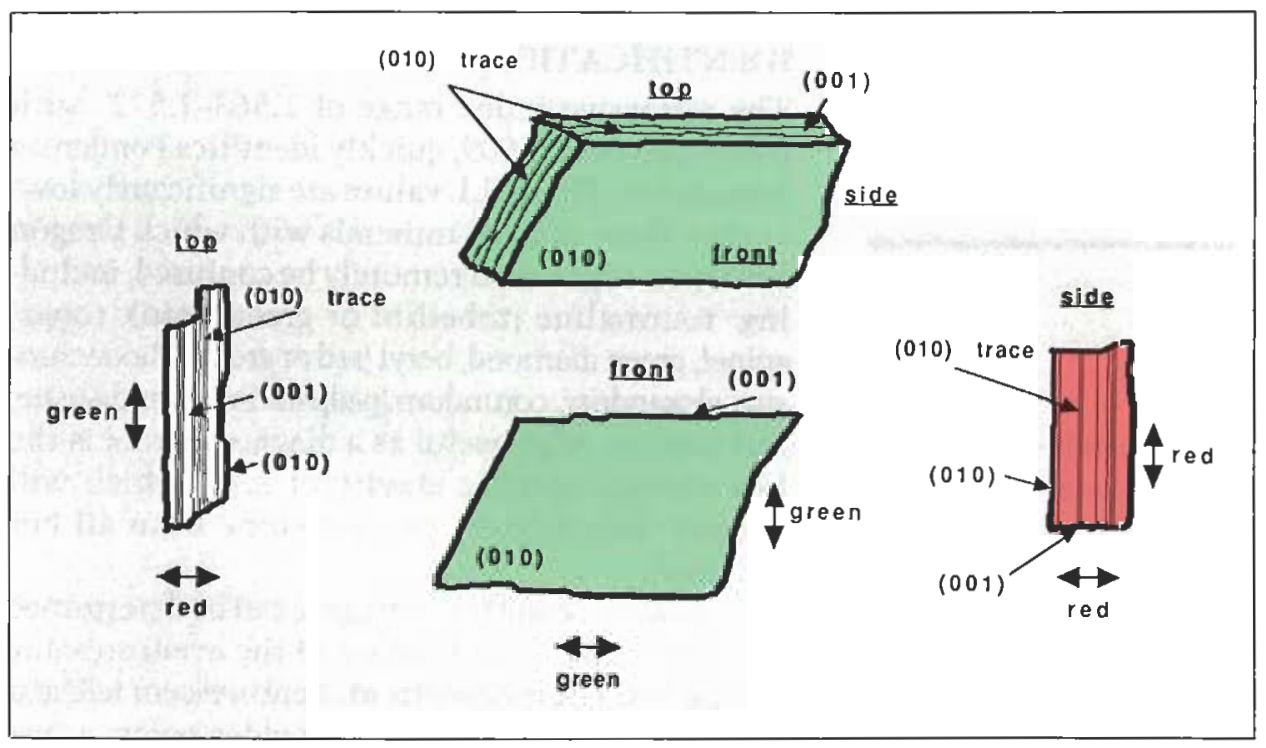

Figure 17. This stylized crystal drawing shows the relationship of pleochroism to crystal form in the Ponderosa sunstones. 


\begin{tabular}{|c|c|}
\hline Property (No. samples) & Observations \\
\hline Color & $\begin{array}{l}\text { Moderate to heavily saturated } \\
\text { red, pink, orange, and green. } \\
\text { Because of pleochroism, some } \\
\text { stones exhibit purples } \\
\text { and deep plums when cut at } \\
45^{\circ} \text { to twin planes. }\end{array}$ \\
\hline Clarity & $\begin{array}{l}\text { All stones exhibit characteristic } \\
\text { inclusions of copper lamellae } \\
\text { that cause aventurescence. } \\
\text { Other types of inclusions are } \\
\text { very rare, and include spinel. }\end{array}$ \\
\hline \multicolumn{2}{|l|}{ Refractive indices } \\
\hline $\begin{array}{l}\text { Single-crystal spindle } \\
\text { stage (1) } \\
\text { Gem refractometer (20) }\end{array}$ & $\begin{array}{l}\alpha=1.5637(2), \beta=1.5681(1), \\
\gamma=1.5728(2) \\
1.563-1.572\end{array}$ \\
\hline \multicolumn{2}{|l|}{ Birefringence } \\
\hline $\begin{array}{l}\text { Single-crystal spindle } \\
\text { stage (1) }\end{array}$ & 0.0091 \\
\hline Gem refractometer $(20)$ & 0.009 \\
\hline Optic sign & Biaxial $(+)$ \\
\hline Twinning & $\begin{array}{l}\text { Common albite twinning is } \\
\text { often visible at low magnifi- } \\
\text { cation }(<10 \times) \text { under polarized } \\
\text { light. Twin planes are usually } \\
1-5 \mathrm{~mm} \text { thick. Carlsbad and } \\
\text { pericline twinning may also be } \\
\text { present, but are visible only in } \\
\text { thin section. }\end{array}$ \\
\hline Cleavage & $\begin{array}{l}\{001\} \text { perfect, }\{010\} \text { good, } \\
\{100\} \text { parting. Cleavage } \\
\text { and parting have no effect on } \\
\text { cutting or setting. }\end{array}$ \\
\hline Specific gravity & \\
\hline $\begin{array}{l}6 \mathrm{fac} \\
6 \mathrm{cab}\end{array}$ & $\begin{array}{l}2.68-2.71 \\
2.67-2.72\end{array}$ \\
\hline Pleochroism & $\begin{array}{l}\text { Very strong when present. } \\
\text { Always present in stones that } \\
\text { exhibit green body color; green } \\
\text { observed parallel to }(010) \text { and } \\
\text { red perpendicular to }(010) \text {. }\end{array}$ \\
\hline $\begin{array}{l}\text { U.V. luminescence } \\
\text { (57, all colors) }\end{array}$ & $\begin{array}{l}\text { Inert to both long- and } \\
\text { short-wave } \\
\text { U.V. }\end{array}$ \\
\hline
\end{tabular}

microscope fitted with a Supper spindle stage and an X-ray goniometer head, as well as an infinitely variable visible light spectrum monochromator and a temperature-variable liquid immersion cell. Using the extinction data, we determined the $2 \mathrm{~V}$ to be $83.4^{\circ}( \pm 0.1)$. Refractive indices of $\alpha, \beta, \gamma$ were determined to be $1.5637(2), 1.5681(1), 1.5728(2)$, respectively. Birefringence was calculated to be $\Delta=0.0091$.
Specific Gravity. The specific-gravity values for six faceted stones $(0.50-2.5 \mathrm{ct})$ and six cabochons $(1.45-$ $4.60 \mathrm{ct} /$ were determined using standard hydrostatic methods. The measured values correspond well with values reported in the literature for labradorite in general (Hurlbut and Klein, 1985). Although the copper inclusions had no obvious effect on specific gravity, their presence may account for the fairly broad range of specific gravities, 2.67-2.72.

Reaction to Ultraviolet Radiation. Twenty-five faceted, eight cabochon, and 57 rough samples were exposed to long-wave $(366 \mathrm{~nm})$ and short-wave (254 $\mathrm{nm}$ ) ultraviolet radiation. All pieces examined were inert to U.V. radiation.

Inclusions. The copper platelets are reflective, a distinct orangy yellow, and appear as rounded ovals in plane view (again, see figure 12); they are nearly undetectable in cross section, average $500 \mathrm{~nm}$ across, and rarely exceed $100 \mu \mathrm{m}$ in longest surface dimension.

Other inclusions in Ponderosa mine sunstone are rare. Dendritic manganese staining has been occasionally noted on partially detached cleavage surfaces, but such stains are not likely to be encountered by the trade as they are usually removed when the rough is prepared for cutting.

A few small $(0.1$ to $0.5 \mathrm{~mm})$, gray to black, opaque mineral grains with submetallic luster were also observed. One of these grains was removed from a crystal and its bulk chemistry analyzed on an SEM with EDX. It was identified as spinel.

\section{IDENTIFICATION}

The refractive index range of 1.563-1.572, with birefringence of 0.009 , quickly identifies Ponderosa labradorite. These R.I. values are significantly lower than those of most minerals with which Oregon sunstone might even remotely be confused, including: tourmaline (rubellite or green), pink topaz, spinel, green diamond, beryl (red or green), rhodochrosite, alexandrite, conundum (padparadscha), andalusite, and cuprite. Also useful as a diagnostic tool is the low average specific gravity of 2.71 , which will quickly differentiate this sunstone from all but red beryl.

Locality origin (i.e., Oregon) can be determined visually by $10 \times$ examination of the aventurescing inclusions. The inclusions in aventurescent feldspar from India have a distinctly redder color, a less 
reflective dull metallic luster, an angular or euhedral crystal habit, and are an order of magnitude larger than those from Oregon. On $10 \times$ examination, even the facet-grade material from Oregon will show some copper platelets. In many faceted stones, copper platelets are visible to the unaided eye (figures 6 and 7$)$.

The distinct red-to-green pleochroism, when present, can also be used to identify the locality origin of Oregon sunstone. No other gem mineral, including labradorite from other localities, exhibits this same distinct red-to-green pleochroism. The pleochroism of andalusite, while strong, is yellow, olive, and red-brown to dark red. Alexandrite has very weak reddish yellow to light green pleochroism. The strong red-to-green color change in alexandrite occurs only with change in wavelength of light, and it is not a specific function of crystallographic orientation. Oregon sunstone exhibits no color change related to light wavelength.

\section{CONCLUSIONS}

The Ponderósa mine in northwestern Harney County, Oregon, is now the world's premier location for both facet- and cabochon-quality sunstone labradorite feldspar. Current known ore reserves at the Ponderosa mine suggest at least 20 years of production at the one-million-carats-per-year level. By comparison, current estimates suggest that the Plush area is capable of producing at the 250,000- carats-per-year level. No other known deposit produces or historically exhibits as wide a range of colors, as well as pleochorism and aventurescence in three directions.

The present study concludes that the aventurescence is a result of the precipitation of copper platelets driven by decreasing pressure and temperature during formation. While no cause of color was positively identified, it is suggested that the intense color in these gems may be the result of intervalence charge transfer between unknown metal ions, possibly involving copper. Specifics of both the color mechanism and the origins of the aventurine effect are the topics of additional study currently in progress.

The key identifying characteristics of Ponderosa mine sunstone include refractive index and specific gravity. Finally, both the copper inclusions and the presence of strong red-to-green pleochroism provide proof that the locality of origin is Oregon.

\section{REFERENCES}

Andersen O. (1917) Aventurine labradorite from California. American Mineralogist, Vol. 2, p.91.

Bloss F.D. (1981) The Spindle Stage: Principles and Practices. Cambridge University Press, Cambridge, England.

Brown D.E., McLean G.D., Black G.L. (1981) Preliminary Geology and Geothermal Potential of the Southern Harney Basin. Oregon Department of Geology and Mineral Industries, Open File Report 0-80-07.

Emmons R.C. (1928) The double dispersion method of mineral determination. American Mineralogist, Vol. 13, pp. 504-515.

Gunter M.E., Bloss F.D., Su S.C. (1989) Computer programs for the spindle stage and double variation method. Microscope, Vol.37, pp. 167-171

Hofmeister A.M., Rossman G.R. (1985) Exsolution of metallic copper from Lake County labradorite. Geology, Vol. 13, No.9, pp. 644-647.

Hopkins F.K., Brown G.J. (1991) Light scattering by inclusions in crystals. Applied Optics, Vol. 30, No. 4, pp. 384-386

Hurlbut C.S. Jr., Klein C. (1977) Manual of Mineralogy, 19th ed. John Wiley \& Sons, New York.

Jenks M.D., Bonnichsen B. (1989) Subaqueous basalt erup- tions into Pliocene Lake ldaho, $\ln$ V. E. Chamberlain, R. M. Breckenridge, and B. Bonnichsen, Eds., Guidebook to the Geology of Northern and Western Idaho and Surrounding Area: Idaho Geological Survey Bulletin, Vol. 28, pp. 17-34.

Nassau K. (1983) The Physics and Chemistry of Color. John Wiley \& Sons, New York.

Peterson N.V. (1972) Oregon "sunstones." Ore Bin, Vol. 34, No. 12, pp. 197-215.

Pough F.H. (1983) Heliolite, a transparent, facetable phase of calcic labradorite. lournal of Gemmology, Vol. 18, No. 6, pp. 503-514.

Powers H.A. (1932) The lavas of the Modoc Lava-Bed Quadrangle, California. American Mineralogist, Vol, 17, No. 7, pp. 253-294.

Stewart D., Walker G.W., Wright T.L., Fahey I.J. \{1966\} Physical properties of calcic labradorite from Lake County, Oregon. American Mineralogist, Vol. 51, pp. 177-197.

Stookey S.D., Beall G.H., Pierson J.E. (1978) Full-color photosensitive glass. Journal of Applied Physics, Vol. 49, No. 10, pp. 5114-5123. 